\title{
Interaction, Ideology, and Practice in Mental Health Rehabilitation
}

\author{
Taina Valkeapää · Kimiko Tanaka • Camilla Lindholm • Elina Weiste • \\ Melisa Stevanovic
}

Received: 15 October 2018/Accepted: 13 December 2018/Published online: 29 December 2018

(C) The Author(s) 2018

\begin{abstract}
This paper investigates how two ideologies of mental health rehabilitation-recovery ideology and communal approach-are realized in interactional practices associated with psychosocial rehabilitation. More spesifically, the paper discusses employee selection in the context of the Clubhousecreated Transitional Employment (TE) programme, which offers employment opportunities for rehabilitants. The paper describes how joint decisions are established during the moment-by-moment interactional processes at the Clubhouse. Drawing from the data set of 29 video-recorded rehabilitation group meetings, and Conversation Analysis as a method, the paper analyzes two questions: (1) How do the participants talk about the decision-making process associated with the TE on a "meta" level? And (2) how are the TE employees actually selected in the turn-by-turn sequential unfolding of interaction?
\end{abstract}

T. Valkeapää $(\bowtie) \cdot$ C. Lindholm · E. Weiste Department of Finnish, Finno-Ugrian and Scandinavian Studies, University of Helsinki, Helsinki, Finland e-mail: taina.valkeapaa@helsinki.fi

\section{K. Tanaka}

Department of Social Welfare, Tokyo University and Graduate School of Social Welfare, Tokyo, Japan

M. Stevanovic

Faculty of Social Sciences, University of Helsinki, Helsinki, Finland
When discussing the TE employee selection procedure on a "meta" level, the values of recovery ideology focusing on client empowerment and selfdetermination are prevalent. Also, the central ideals of the communal approach-openness and collaboration-are defended as decision-making guidelines. However, in the meetings where decisions on the TE employees are concretely made, there is a mismatch between the two ideological approaches to rehabilitation and the actual practices observable in the relevant interactional encounters.

Keywords Rehabilitation - Professional ideology · Joint decision-making $\cdot$ Conversation analysis $\cdot$ Social interaction

\footnotetext{
"We made a democratic selection with the members who were interested in the job. It was a joint decision and the selection process went really well." - Support worker evaluates a selection process of a transitional employment worker.
}

\section{Introduction}

According to WHO [1], mental disorders affect over 300 million people worldwide, being more common than cancer or heart disease. Mental illness has a significant effect on human productivity, constituting a tremendous burden on the global economy [2]. Most of these costs are caused by mental illness reducing individuals' ability to enter and stay active in the labour market $[3,4]$. This problem becomes more 
serious due to potential employers often being reluctant to hire people with mental illness [5, 6]. For instance, in Finland, as much as 59\% of private service sector companies expect negative consequences from employing people with mental illness [7]. This attitude also reverberates in the beliefs of mental rehabilitants: $77 \%$ of rehabilitants believe that if the work community knows about the employee's mental health problems, it can lead to a loss of job, status or appreciation [8].

The high unemployment rate of individuals with mental illness has led to a variety of programmes created to enhance the chances of employment in this group. Common to all of these programmes is the endeavour to enhance the experiences of empowerment and social inclusion for persons with mental health problems. These programmes are designed to reduce discrimination and stigma around mental illness and to improve mental health services to foster the clients' empowerment [9, 10]. Empirical studies have shown that, among people with mental illness, experiences of empowerment are particularly beneficial. These experiences have been shown to be related to improved quality of life [11], stigma resistance $[12,13]$, a lessened degree of internalization of the stigma [14, 15], a larger social network [16, 17], and better physical health and illness recovery [18].

There are many ideological approaches to psychosocial rehabilitation and these depict mental illness and its underlying reasons in slightly different ways. Recently, one of the main models of rehabilitation involves a specific emphasis on recovery. Whereas traditional psychiatric treatment focuses on patients' symptoms and functioning, the recovery approach focuses on a non-linear process of continual growth that builds the resilience of people with mental illness (e.g. [19-21]). Recovery can be viewed as an overarching philosophy that encompasses notions of selfdetermination, self-management, empowerment, and choice [22]. It is about enabling and supporting individuals with mental illness to take control over their own lives. Overall, all interventions used should be designed to promote people's personal agency. Other approaches to mental rehabilitation place greater emphasis on communion as a mental health resource. Almost 60 years ago, R.D. Laing described how the experiences of "being with" in a comfortable and safe environment contribute to the mental health patient's ability to form bonds with others and to become more sociable [23]. Laing's contention was that mental illness arises in part from social and societal alienation. A similar emphasis on communion can also be seen in the Open Dialogue approach to psychological distress, practised in Western Lapland, Finland [24]. In these views, communion is a central precondition for empowerment [25].

In this paper, we investigate how the ideals of the two broad approaches described above-(1) the recovery ideology and (2) the communal approach to mental health rehabilitation-are realized in decisionmaking processes associated with one specific programme that has been designed to pave the way for employment opportunities for persons with mental illness. This is the Transitional Employment (TE) programme organized by the Clubhouse International, a non-profit organization coordinating a global network of Clubhouse Communities. In what follows, we will first introduce the Clubhouse model of psychosocial rehabilitation and discuss its relationship to the recovery ideology and the communal approach. We will then describe more closely the TE programme. Thereafter, we will move to the main section of the paper, where we provide a detailed analysis of real-life decision-making encounters which took place in the context of one lengthier TE process at a Finnish clubhouse.

The Ideological Foundations of the Clubhouse Model

The Clubhouse model of psychosocial rehabilitation has long been recognized as one such approach that promotes employment among persons with mental illnesses. The model originated in the early 1940s and was inspired by the recovery ideology of AA meetings [26]. It provides community-based programmes whose goal is to support mental rehabilitants (henceforth referred to as "members") to live a self-directed life and to reach their full potential [27, 28]. Clubhouse documents in its Clubhouse Standards [29] operational principles and guidelines including a strengths-based philosophy and the right to self-determination.

Recent Clubhouse literature has begun to reclaim the recovery ideology embodied in the model [27, 30-36]. Raeburn et al. [32], for instance, reviewed samples of key programme documents within an Australian Clubhouse to assess how they reflect 
recovery ideology. A content analysis yielded 166 recovery-oriented phase references, which were classified into collaboration (28\%), acceptance and participation (25\%), quality improvement (18\%), consumer and staff development (15\%), and selfdetermination (15\%). In their two subsequent qualitative case studies, Raeburn et al. [33, 34] described how recovery-oriented practices are implemented in staff behaviour on the basis of data from participant observation and interviews in the same Clubhouse context. The results show that staff appreciated the members' opinions and encouraged members to express themselves in decision-making situations [34]. Moreover, members, although they were encouraged to participate in Clubhouse activities, had autonomy whether to choose to join in or not [33].

In addition to the recovery ideology, the Clubhouse model is also inspired by the communal approaches described above. In the Clubhouse model, the workordered day is central [27, 29]. Unlike business workplaces or conventional prevocational programmes, the work-ordered day involves members and their support workers mutually helping each other to run the community. Instead of developing skills and habits, the primary goal of work is to build trusting relationships and a sense of communion [27]. These experiences have been shown to help members to regain their self-confidence in their ability to accomplish things, as well as to rediscover their social values as citizens, which may include vocational aspirations [35-37]. Although the Clubhouse model advances both collective and individual benefits [38], the benefits of the collective have been considered to be the primary guidelines for the activities [39].

From the point of view of both the recovery and communal approaches to rehabilitation, everyday decisions at the Clubhouse are a central locus where the ideals of the two ideologies come into being - that is, decision-making processes at the Clubhouse should be kept as democratic as possible. However, studies on this topic reveal challenges in this matter. An organizational study conducted by Mowbray et al. [40], show a limited degree of members' involvement in administrative decision-making, meaning decisions about budgeting or the rules and guidelines of the Clubhouse. Previous studies have also shown that although the overall decision making in the Clubhouse has tried to keep as democratic as possible, some members have more influence over the decision-making process than others [41], and at times the staff members' opinions overrule the members' opinions because of the staff's position [42]. Clubhouse literature (e.g. [34, 35, 42]) seems, however, to primarily illustrate decision-making experiences associated with work-ordered day voluntary work in running the Clubhouse; not much is written about individual support for life in the broader community, such as employment. To pursue this line of inquiry, observation that focuses on interactions are useful to tune into the subtleties and nuances embedded in decision-making processes, as they unfold in a series of sequential moment-to-moment behaviours between people.

\section{The Case of Transitional Employment}

Clubhouse has also been keen to assist members in gaining employment to reinforce their recovery in the broader community [28, 29]. The Clubhouse members who wish to seek work in the competitive labour market are supported by the Clubhouse-created TE programme [27]. This programme consists of prevocational training that involves a period of preparation before entering a TE workplace. The overall aim of the programme is to help members develop the skills and confidence needed to be able to return to competitive employment. TE means part-time placements at the employer's place of business, lasting from 6 to 9 months. The selection and training of members, as well as replacements, are managed by the Clubhouse community, not by employers. Members can go through a series of different placements and once they have succeeded in TE they are encouraged to seek competitive employment [43].

The reasons for Clubhouse members to participate in the TE programme include the possibility of evaluating their work-related functional capacity, earning money and exploring the option of returning to competitive employment $[44,45]$. Members' experiences of the programme are generally positive, the most immediate impact of TE being an improvement in the members' quality of life [44]. In Finland, around $10 \%$ of those members that have participated in the TE programme return to competitive employment, and approximately $20 \%$ start their studies [45]. The longer a person participates in Clubhouse activities and TE, the more likely future employment is found [46].

The TE programme-like any other programme involving human agents-ultimately takes place in 
social interactions between people. TE workplaces are created in interactions between the representatives of the Clubhouse organization and those of the employer, while the Clubhouse members need to interact with the Clubhouse staff and other members to enter into the programme. According to the more or less publicly discussed "professional stocks of interactional knowledge" [47], among the support workers, the decisions about entrance into employment, which are highly consequential to the Clubhouse members, should be made democratically (see the quotation at the very beginning of this paper). In seeking to enhance the members' opportunities to influence those decisions that are personally meaningful to them, this ideal draws heavily from recovery ideology. But then again, the same ideal of democracy also arises from the communal approach where practices are strongly informed by shared interests and collective benefits. In the analysis of this paper, we examine the interplay between these two ideologies in meetings where members and support workers plan the TE process and make decisions about who will next be given work.

\section{Research Questions}

In this paper, we investigate how the ideals of the recovery and communal approaches are realized in interactional processes associated with the Clubhousecreated TE programme. In our analysis, we will be guided by the following research questions:

(1) How do the participants in the meetings talk about the TE process and the associated decision-making procedures on a "meta" level?

(2) How do the participants actually make employment-related decisions in the turn-by-turn sequential unfolding of interaction?

\section{Data and Methods}

The data consist of 29 weekly meetings of a mental rehabilitation group. The data were collected during September 2016-August 2017 from one Finnish Clubhouse. The aim of the meetings was to prepare the members for TE, to discuss the competencies of the members, and to make decisions regarding the appointees of future TE positions. Each meeting was attended by $2-10$ members and 1-3 support workers trained in social work. The duration of the meetings varied between 30 and $60 \mathrm{~min}$.

This study is a part of a larger research project on the relationship between social interaction and mental health. For the part of the project that involves the collection of diagnosis-based personal data, we obtained ethical approval from the Ethics Committee of the Helsinki University Central Hospital. For the other parts of the project, the study did not meet any of the requirements specified by the Finnish National Board on Research Integrity (https://www.tenk.fi/en/ ethical-review-in-finland) that would have made a university-based ethical review necessary. Instead, research ethics approval was obtained from the Southern Finland Clubhouse Association (date of the decision: 19.09.2016), whereas research permits were given by the board of directors at the relevant Clubhouses. Participation in the project was voluntary. Before signing a consent form, all participants were informed about the aims of the project, about their rights as participants, and about the use, availability and anonymization of data. This happened by means of a letter and in personal encounters with the researchers conducting the study. All identifiable items have been changed in the transcripts used in the analysis.

The data were analysed by means of conversation analysis (CA). CA is a qualitative data analysis method for studying video recordings of naturally occurring interactions to unravel the reoccurring interactional practices through which social actions (such as questions and requests) are constructed in moment-by-moment processes (e.g. [48]). One of the central features of $\mathrm{CA}$ is its examination of how different social actions are organized into sequences, i.e. the ways in which utterances arise from previous utterances and how they control subsequent utterances [48, 49].

In our analytic procedure, the spoken interactions during the meetings were first transcribed according to CA conventions ([48], see Appendix). Next, the recordings were listened to several times and the segments of interaction relating to TE procedures and decisions were discussed. These segments were then qualitatively analysed case by case to specify the nature and variation of the phenomenon in question, paying attention to their primary interactional function, content, lexical design and implications for social 
action. The data extracts presented in this paper have been selected on the basis of their capacity to demonstrate the critical parts in the larger TE process at the given Clubhouse.

\section{Results}

In this section, we analyse two different interactional contexts related to the selection of TE workers. First, we present data in which the participants discuss the procedures and decision-making process of TE without making actual decisions. Second, we study the sequential unfolding of decision making related to TE.

Discussing the Selection Procedure of a TE Worker

Extracts 1-3 are drawn from a meeting in which ten members and two support workers discuss the practical procedures related to the selection of the TE worker. Extract 1 (see Box 1) illuminates contradicting views between Clubhouse members and support workers regarding the selection process.

Initially, the support worker outlines the selection process (1. 1-4). Her multi-unit turn contains various prefatory declarative units providing a background for the question-formed proposal in line 5 (cf. [50]). Even though her question is addressed to the whole group, only Kaisa answers (1. 7). Her response is followed by a lengthy pause, during which the support worker looks at the other members, apparently in an attempt to provoke an answer (cf. [51]; gaze as a resource for mobilizing a response). Nobody volunteers, and the support worker produces another question (1. 9). At this point, Kimmo responds (1.11) by confirming the proposition outlined in the support worker's previous turn. Member Laura, on the other hand, initiates repair by expressing a failure to grasp the contents of the support worker's prior turn (1. 14). In 1. 21-22, Laura responds to the support worker's reformulation of her proposal. Laura's turn contains the negative verb phrase etteks te ('don't you'), indicating that her understanding is that the support workers, not the group, choose the workers for TE. On the face of it, Laura's turn is an information-checking question, but, implicitly, it appears to involve an assessment of the sensibility of her prior understanding in contrast to the one expressed by the support workers. Therefore, one might argue that Laura's turn also expresses a contradictory opinion. The support worker's response (1. 24-25) repairs Laura's previous turn and emphasizes that the procedure for the selection process isn't ready-made but under consideration. However, after this Pasi (1. 26) expresses a preference for the support workers choosing the person for TE. He also produces an account for this opinion-he doesn't know other members.

As the interaction proceeds to extract 2 (see Box 2), the support worker gives an account of how the members should pitch themselves to the TE by telling about their strengths $(1.1-2,4,6)$. At this point, Laura agrees with the preferred procedure of the support workers, although the turn-initial modal particle kai ('perhaps') also displays hesitation (1. 7, 9, 13-14 and 16). Thus, Laura simultaneously aligns with the prior turn and expresses uncertainty with its contents.

The support worker goes on to describe why it is preferable that the group, not the support workers, chooses the TE worker (1. 18-21). Interestingly, the support worker then presents the idea about the selection process as Laura's proposal (1. 24). In a previous study [52], we demonstrated how staff members can categorize members' turns as proposals as an endeavour to increase the participation of the members. The support worker nominates Laura as the principal of the proposal, even though it was originally formulated by the support workers. In her response (1. 26), Laura aligns with the prior turn. However, she uses the expression seki ois hyvä joo ('that would also be good yes'). The enclitic particle $k i(n)$ ('too, also') conveys Laura's agreement with the suggestion outlined in the prior turn, but also hints at the existence of alternative suggestions. Support worker 1 confirms Laura's turn with the minimal response particle niin ('yeah') (1.27). Thus, the activity proceeds in the direction originally proposed by the support workers: the members interested in TE would introduce themselves and the candidate would be nominated as a result of a group-internal decision.

Boxes 1 and 2 demonstrate how the support workers' opinions on the one hand overrule the opinions of the Clubhouse members, but how on the other hand they make an additional effort to construct the decisions related to the selection procedure made as joint decisions. The support workers' actions can be 
Box 1 Extract 1: Selection procedure 1 (SW1, SW2 = support workers; Kaisa, Kimmo, Laura, Pasi = Clubhouse members)

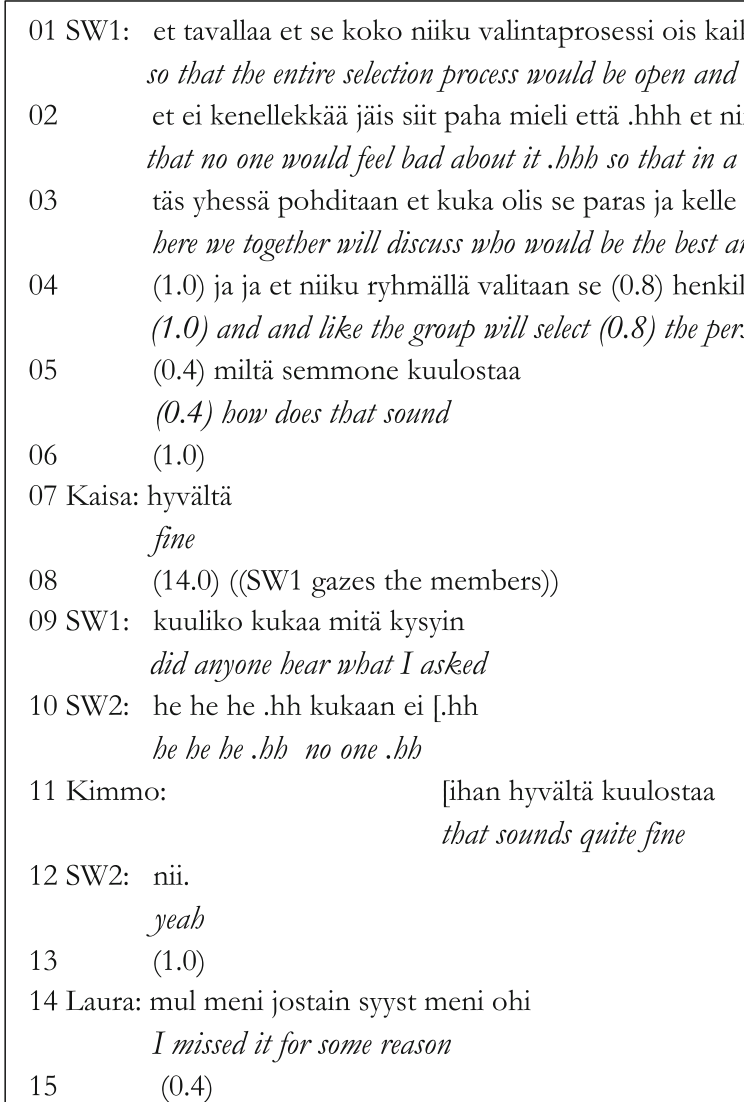

16 SW1: nii että olisko se ihan ookoo että tässä ryhmällä ne ketkä olis kiinnostunu siitä työpaikasta so would it be OK that here in this group those who would be interested in the job

17 ja ilmottais kiinnostuksensa ja ryhmässä .hhh tehtäis se valinta että (.) and would make the interest known and within the group. hhb we would make the selection (.)

18 että kuka se heistä olis ettei niinku (0.2) työntekijät salaa tuola suputtelis että that which one of them would be it so not like (0.2) staff members would secretly chat there

19 .hhhh valitaan Mika vaan että tää ryhmä tässä ketä on ni kaikki puhuis ääneen että .hbhb let's select Mika but on the contrary this group here everyone would speak aloud that

$20 \quad(0.2)$ kuka o[lis se hyvä ja

(0.2) who would be good and

21 Laura: $\quad$ [etteks te

don't you

22 Laura: etteks te tee just sillee et te itte päätätte se don't you do exactly so that you decide by yourself

$23 \quad(0.2)$

24 SW1: eiku tässä me just mietitään et mikä olis niinku teidän mielestä se paras keino (0.4)

no bere we right now consider what would be to your mind the best way (0.4)

25 tai meidän kaikkien mielestä

or to our all minds

26 Pasi: mielummi te valitsette hh en tunne ketään tästä (.) en tunne

preferably you select bh I don't know anyone bere (.) I don't know 
Box 2 Extract 2: Selection procedure 2 (SW1, SW2 = support workers; Laura, Juha = Clubhouse members)

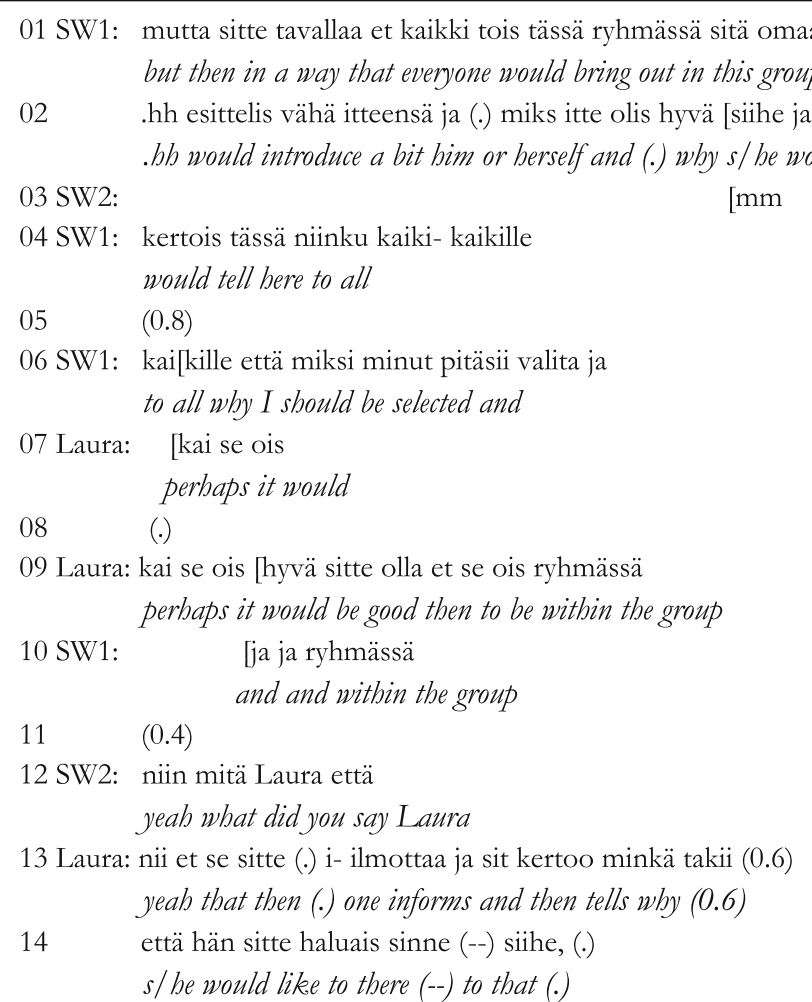

15 SW1: $\mathrm{mm}$.

16 Laura: [työjuttuu et se voi (.) [(nii) to the job that it can (.) (yeab)

17 SW2: [nii [nii yeab yeab

18 SW2: koska on aika vaikee et jos tässä nyt oltas (.) porukalla ja meiän pitäs nyt päättää tästä because it's quite difficult if we would be here now (.) all together and we should now decide

19 et se ois vaikka kolme (0.6) miestä rivissä jotka haluaa lähtee siihen työpaikkaan ni (1.2) that there would be for example three (0.6) men in a row who all want to get that job so (1.2)

20 millä me se päätös tehdään ku (0.4) toivois että kaikki pääsee bow do we make the decision when (0.4) one would hope that everyone could get

21 et täytyyhän siin joku tämmönen (0.4) eikä me tunneta kaikki toisiamme niin hyvin et on vaikee so there has to be something like this (0.4) and we don't know each other so well that it's hard

22 SW1: $\mathrm{mm}$

23 Laura: hhhh okei bhb okay

24 SW2: että mitä toi Lauran ehdotus tai se mitä sanoit ni se vois olla so Laura's proposal or what you said it could be

25 niinku mun [mielest ainaki hyvä at least to my mind it could be good

26 Laura: [se ois mun miel- mun mielest seki [ois hyvä joo

27 SW2: that would be to my mind that would also be good yes [nii yeab 
Box 3 Extract 3: Selection procedure 3 (SW1, SW2 = support workers; Juha, Riku = Clubhouse members)

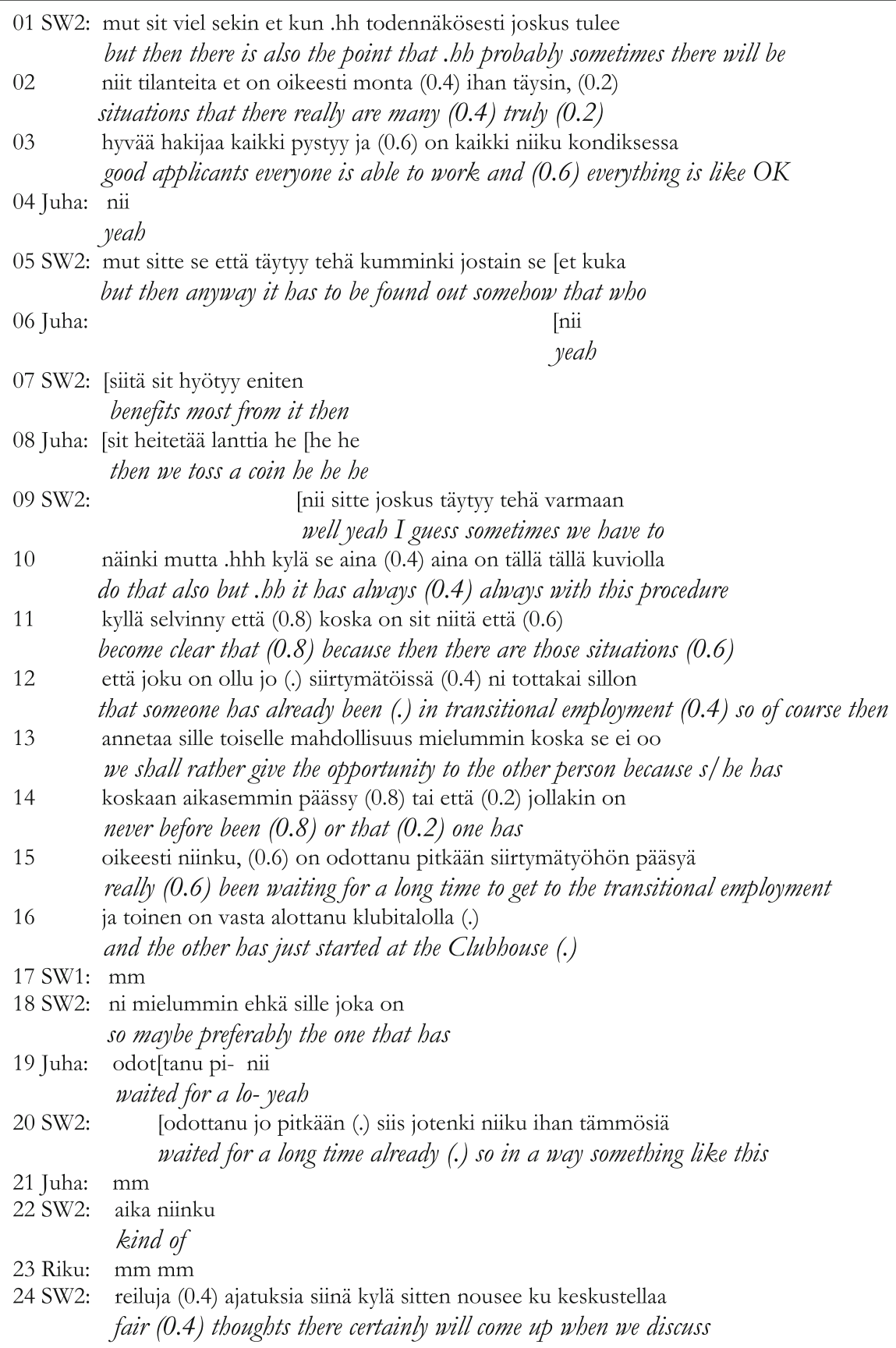

understood in terms of both, the recovery ideology and the communal approach. In their turns, the support workers empower members by encouraging them to demonstrate their strengths and willingness to get the TE place. Support workers also emphasize openness, democracy and collaboration during the selection 
Box 4 Extract 4: TE worker interview 1 (SW 3 = support worker; Mari = Clubhouse member)

\begin{tabular}{|c|c|}
\hline 01 SW3: & $\begin{array}{l}\text { onneks täs on semmonen iloinen tilanne meillä että meillä on } \\
\text { luckily we have such a happy situation bere that we have }\end{array}$ \\
\hline 02 & $\begin{array}{l}\text { ihan älyttömän hyvät hakijat tässä haastattelussa ja ja sitten } \\
\text { such great applicants in this interview and and then }\end{array}$ \\
\hline 03 & $\begin{array}{l}\text { kaikilla on kokemusta alalta (1.0) toisilla ehkä vähän enemmän alalta } \\
\text { everyone has experience in the field (1.0) some have maybe a bit more }\end{array}$ \\
\hline 04 & $\begin{array}{l}\text { ja toisilla vähän vähemmän mutta kaikilla on ninkun alalta kokemusta } \\
\text { and the others a bit less but everyone does have experience in the field }\end{array}$ \\
\hline 05 & $\begin{array}{l}\text { että sekään ei oo ninku pullonkaula } \\
\text { so that's not a problem either } \\
\text { ((20 lines omitted }))\end{array}$ \\
\hline 06 SW3: & $\begin{array}{l}\text { ootte kyllä ollu ahkeria ootte tehny niitä hommia .hhh } \\
\text { you have been very hard-working and you have done jobs .hbh }\end{array}$ \\
\hline 07 & $\begin{array}{l}\text { (0.3) on oma-alotteisuuttaki löytyy ja säännöllisyyttä löytyy ja ja ja } \\
(0.3) \text { you have also shown initiative and regularity and and and }\end{array}$ \\
\hline 08 & $\begin{array}{l}\text { muita asioita löytyy et et et ninku et (0.5) et ainoo mitä (.) mä tossa } \\
\text { other things so so so like (0.5) so the only thing that (.) I was }\end{array}$ \\
\hline 09 & $\begin{array}{l}\text { (0.5) mitä (.) Mari toi pikkusen sitä että (.) Marilla on varmaan } \\
(0.5) \text { what (.) Mari brought out that (.) Mari has probably }\end{array}$ \\
\hline 10 & $\begin{array}{l}\text { niin just toi se on rehellisyyttä se että tuntee itsensä } \\
\text { like that it's honesty that one knows oneself }\end{array}$ \\
\hline 11 & $\begin{array}{l}\text { musta Mari toi sen tosi hienosti tossa että }(0.4) \\
\text { I think. Mari brought it out very well that }(0.4)\end{array}$ \\
\hline 12 & $\begin{array}{l}\text { mä kirjasin sen tänne koska se oli musta ninku hyvä asia } \\
\text { I wrote it down here because I think, it was a good thing }\end{array}$ \\
\hline 13 & $\begin{array}{l}\text { että sen ninku tunnistaa itsessään niitä kehittämisen alueita ni } \\
\text { that one recognizes the areas of oneself that need to be improved }\end{array}$ \\
\hline $\begin{array}{l}14 \\
15 \text { SW3: }\end{array}$ & $\begin{array}{l}(0.7) \\
\text { sä täällä (.) sanot että tota ni että se oma-alotteisuus on } \\
\text { you here (.) say that the power of initiative is }\end{array}$ \\
\hline 16 & $\begin{array}{l}\text { varmaan se mitä pitää kehittää (0.6) koska se on semmonen (.) } \\
\text { probably the thing that needs to be improved (0.6) because it is kind of (.) }\end{array}$ \\
\hline 17 & $\begin{array}{l}\text { kyllä tosi tärkeä ominaisuus }(0.3) \text { ja mää (.) mää tunnistan (.) } \\
\text { indeed a very important quality (0.3) and I (.) I recognize (.) }\end{array}$ \\
\hline 18 & $\begin{array}{l}\text { jos mä ihan rehellinen oon ni kyl mää (.) Mari tunnistan että } \\
\text { if I'm completely honest I do (.) Mari recognize that }\end{array}$ \\
\hline 19 & $\begin{array}{l}\text { se on varmaan se sulla se (0.4) mitä sä pystyt kehittään täällä } \\
\text { it is probably the area you (0.4) are able to still improve bere }\end{array}$ \\
\hline 20 & $\begin{array}{l}\text { klubilla vielä } \\
\text { at the Clubhouse }\end{array}$ \\
\hline 21 Mari: & $\begin{array}{l}\text { joo } \\
\text { yeab }\end{array}$ \\
\hline
\end{tabular}

process-all the members, not only the support workers, are presented as those who are in control of the decisions. However, as the interaction proceeds to extract 3 , the value of communality is highlighted as a main guideline of decisions.
Extract 3 (see Box 3) presents how the support worker introduces a hypothetical scenario involving many devoted and eligible members and initiates a discussion on how a decision could be made under such circumstances. 
The support worker outlines a situation involving many competent applicants who meet the criteria decided upon earlier in the discussion (1. 1-3). As new criteria, she first names the advantage of the TE worker (1. 7): the person who benefits most should be selected. Further, she identifies first-timers (1. 13-14) and then persons who have waited for a TE place for a long time $(1.18,20)$ as preferable candidates. Apart from the criterion of being a first-timer, these criteria are quite imprecise and subjective so that no definite conclusions about who should be selected can be made on the basis of the criteria alone. Thus, the criteria are presented as examples through which the support worker illustrates the hypothetical decision-making situation and underlines the importance of fairness (1. 24) to other members. As mentioned earlier, although the Clubhouse model advances both collective and individual benefits [38], the benefits of the collective are considered the primary principle [39]. Fairness towards others, which is at the heart of the communal approach, is presented as a main guideline of the decision making. This, however, is related to a potential paradox. On the one hand, Clubhouse members are asked to stress their superiority in competitive situations, but on the other hand, they are supposed to be "unselfish" and follow the communal values in actual decision-making encounters.

\section{Choosing the TE Worker}

We will now proceed to study how the selection of a TE worker is conducted in sequentially unfolding interaction. Extract 4 (see Box 4) features an interaction involving three members who take an interest in an open TE position and two support workers. Prior to the extract, the support worker requested the members to say something about their strengths and work experience. In extract 4, the support worker summarizes the interview so far.

Initially, the support worker praises all three candidates and emphasizes the difficulties in selecting one person (1. 1-7). The praise is, however, followed by her account of one area of improvement for Mari. The support worker refers to Mari's own description of her primary weakness (1. 15-16), and also provides an opinion that is aligned with Mari's self-evaluation (1. 18-19). The support worker continues by describing the Clubhouse as a fruitful context for improvement in this area (1. 19-20). Through this turn-by-turn sequential unfolding of the interaction, a suggested field of improvement is transformed into a criterion that excludes Mari from the selection process. With her token joo ('yeah') (1. 21) Mari agrees to being excluded. Thus, extract 4 illuminates how the support worker decides the key criterion by herself, gives a personal evaluation of the member, and in this way strongly directs the selection process.

Excerpt 5 (see Box 5) provides another example of the selection of a TE worker. Here, the support worker suggests that the members make the selection by voting (1. 1).

The voting procedure results in Paula getting the most votes. The support worker responds to the result only minimally with the response particles (1. 11). Thus, she appears to dismiss the result instead of declaring Paula the winner. After a long silence (1. 12), the support worker notifies that the group should collaborate to come up with a decisive criterion (1.13). The members remain silent (see 2.4 s silence in line 13) and the support worker goes on to express her own opinions on the candidates (1.14). As in extract 4 (see Box 4), the support worker first emphasizes the similarities between the candidates (1. 14-15) and then introduces random criteria that are framed as significant for the selection process and in terms of which the candidates are different. Initially, the support worker names 'regularity', which is introduced as the only differing feature between the candidates (1. 17-18). The support worker's turn contains the turn-final question particle eikö ('right') (1. 18), which indicates that she is seeking for aligning responses from the other participants. However, no such responses are given. Then, the support worker proceeds to specify another criterion, 'versatility' (l. 19-20). Now, she explicitly names Paula as somebody who fails to fully meet the criterion (1. 20-21). Again, she uses the turn-final question particle (1.21) in an attempt to pursue an aligning response. Paula, however, does not confirm the support worker's assessment, but defends herself by describing how she would act in professional life $(1.23,26)$. Although the support worker does align with Paula at this point (1. 24-25), extract 5 demonstrates how the support worker directs the selection process towards the ultimate decision of choosing Julia for TE.

The extracts of the selection of the TE worker (Boxes 4 and 5) can be seen as somewhat problematic 
Box 5 Extract 5: TE worker interview $2($ SW 3; Katja = support workers; Matti, Julia, Paula = Clubhouse members)

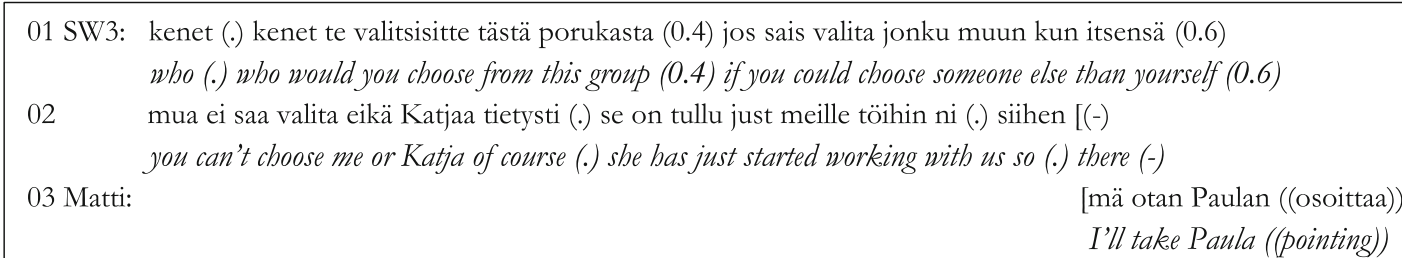

04 SW3: sä valitsisit Paulan ja (0.8) ketäs Paulan valitsis jos ei ketään muu you would choose Paula and (0.8) who would Paula choose if not anyone else

05 ((Paula points at Julia))

06 SW3: Julian

Julia

$07 \quad(0.6)$

08 Julia: ja mä valitsisin myös Paulan [hhh and I would also choose Paula hbh

09 SW3:
[nii sä valitsisit myös Paulan
yeah you would also choose Paula

$10 \quad(0.8)$

11 SW3: kyllä (0.6) jooh

right (0.6) yeab

$12 \quad(5.0)$

13 SW3: sitte meiän täytyy sitä hommaa tota noi ni miettiä et mikä onks joku semmone kriteeri (2.4) mikä on nyt but then we have to kind of think about that is there some criterion (2.4) we could use now

14 (1.0) ku mä musta tuntuu et te ootte molemmat teil on molemmilla ihan samanlaisia noita 0.8) niinkun (1.0) because I feel that you both that you both have exactly the same (0.8) like

15 (2.0) tossa kriteeristöstä mitä aatteli et mistä vois peilata ni teil on tosi paljon niiku samaa (.) (2.0) criteria what one thought could be used so you have a lot of similarities (.)

16 siis molemmilla (.) et teil ei oikeestaa mitään muuta oo sillai eri (.) eri siinä ku mitä mä niiku aattelen I mean you both (.) so that you don't exactly have any other difference (.) difference there than what I see

17 jos mä niiku katon niitä pääjuttuja mitä tuol on ni (.) on se säännöllisyys (.) se on varmaa se ainoo missä if I look at the main points that there are (.) there is regularity (.) that is probably the only thing where

18 teil on vähä erilailla (1.0) tällä hetkellä eikö you have a difference (1.0) at the moment right

19 SW3: ja sitte se että (2.0) että on monipuolisesti kiinnostunu erilaisista tehtävistä ja haluaa kokeilla and then the thing is that (2.0) that one has all-round interests in various tasks and wants to try out

20 kaikenlaista siinä te ootte erilaisia (0.4) mä aattelin Paulaa vaa et sul on aika paljon sitä samaa hommia everything there you differ (0.4) I was just thinking about Paula that you have pretty much the same tasks

21 mitä sä tykkäät tehä (.) eikö that you like to do (.) right

22 SW3: mut [oot sä muutaki tehny but you bave also done other things

23 Paula: [joo mutta kyllä työelämässä ni kyl mä mielellään ni kokeilen kaikkii mahdol[lisii uusii yeah but in working life I really gladly try out all possible new

24 SW3:

[tottakai (0.4)

of course (0.4)

25 mä [uskon sen kyllä

I do believe that

26 Paula: [uusii asioita

new things 
in terms of both ideologies behind the Clubhouse model. The support worker, certainly, tries to empower members by praising their strengths and giving the impression that there is a close-run competition. However, later on the support worker chooses random criteria, makes subjective evaluations of members and dismisses the democratic decision making inside the community. As we will argue further below, it is possible that these interactional practices, although they appear to be against the ideologies behind the Clubhouse, can still be seen as motivated by communal aspects.

\section{Discussion}

In this paper, we have studied how the ideals of the recovery and communal approaches to mental health rehabilitation are realized in naturally occurring decision-making practices in the context of the Clubhouse-created Transitional Employment programme. In the meetings where support workers and Clubhouse members plan the procedure for selecting TE workers, the values of recovery ideology focusing on client empowerment and self-determination are noticeably present. Simultaneously, the support workers also defend the central ideals of the communal approach-openness and collaboration-as guidelines for the selection process. In this vein, the support workers emphasize the value of fairness to other members, which shifts their stance more strongly on the communal side of things, as compared with the ideals of recovery and personal empowerment. However, our study also demonstrates that in the situations where the actual decisions on the TE workers are made, the interactional practices do not appear to match with the ideals of either of the two ideological approaches to rehabilitation. The support worker takes control and directs the selection process, thus dismissing the possibilities of democratic decision making.

To study ideologies in practice has been described as a challenging task (e.g. [31]). In this specific context, however, the first steps in this direction have already been taken. Essentially, several researchers have questioned the model's effectiveness in promoting social integration, or "social recovery" [53-56]. It has been argued that Clubhouse support may inadvertently reinforce "institutional dependency", even though the goal of the model is to free people from it. Also, as pointed out earlier, previous studies on decision making at the Clubhouse have shown that, despite the ideal of democratic decision making, some members affect the decision-making process more than others [41], and at times the staff members' opinions overrule the members' opinions because of the staff position [42]. In this study, we have drawn from this previous body of work, complementing it by investigating naturally occurring interactions. As has been pointed out by Peräkylä and Vehviläinen [47], the CA method can generate concrete descriptions of interactional practices associated with professional ideologies, and in so doing also reveal their "simplified or empirically unsustainable assumptions" ([47], p. 747).

In this paper, we have demonstrated that, although in their talk the support workers stress practices which are in line with Clubhouse ideologies, in actual decision-making situations, however, these ideologies are not always realized. This finding raises the question: Should really all decision-making at the Clubhouse happen jointly? Or, are there decisions, such as the ones surrounding the TE program, which could be better defined as ones where the support workers' assessments carry most weight? On the basis of our findings, it might be worthwhile to consider whether, in some of these areas, an open discussion about the existing power relations could be more fruitful and empowering for the members of the Clubhouse community than the artificial maintenance of the mere illusion of equality.

At the same time, however, the support workers' apparent noncompliance with the Clubhouse ideology may be elucidated with reference to the very ideology on another level. This holds most clearly for the communal ideology when considering the importance of a successful TE programme for the entire Clubhouse community (see [57]). Thus, certainly, the management of the programme is likely to create stress for the support workers, which is reflected most concretely in those situations where a member does not show up at the work site and a support worker would need to make immediate arrangements to go to the work site to solve the issue. Situations such as these highlight the occurrence of TE at the intersection of the Clubhouse community with its own values as a mini-world of its own and the site of TE as something that represents the world external to the Clubhouse community. The support workers are likely to hold 
themselves accountable for the success of the employment ([57], p. 657), perhaps wanting to "play it safe" and select an appointee who would impress at the workplace. This would ensure the continuation of the collaboration between the Clubhouse and the employer. Simultaneously, a reliable worker would be unlikely to create a need for immediate support and arrangements which would challenge the smooth unfolding of everyday life at the Clubhouse. The collective benefit of the Clubhouse is at the heart of the Clubhouse model [39], and as we have demonstrated, it can override the benefits of individuals.

There are certain limitations to the study. Obviously, the relatively small number of participants in our data constrains the generalizability of the resultseven if the size of our data set as such is quite large for the conversation analytic study. In a similar vain, given that all our data come from a very specific context-one Finnish Clubhouse-our results cannot be uncritically applied to other contexts and cultures around the world. Furthermore, as noted at the beginning of the paper, there has been little previous empirical research on decision-making interactions in mental health rehabilitation. This scarcity of literature restricts out possibilities to compare and critically review our findings with and against those of others done in equivalent settings. This paper should therefore be considered as something like a pilot exploration of a new research area, which can then guide and inspire further research. In pointing to the discrepancies between ideologies and practice in the Clubhouse context, the paper suggests that further indepth exploration of interactional practices in the various sites for mental health rehabilitation would clearly be worthwhile.

Acknowledgements Open access funding provided by University of Helsinki including Helsinki University Central Hospital. Research for this study was supported by the Academy of Finland (Grant No. 307630) and the University of Helsinki.

Open Access This article is distributed under the terms of the Creative Commons Attribution 4.0 International License (http:// creativecommons.org/licenses/by/4.0/), which permits unrestricted use, distribution, and reproduction in any medium, provided you give appropriate credit to the original author(s) and the source, provide a link to the Creative Commons license, and indicate if changes were made.

\section{Appendix: Transcription Symbols [48, pp. 265-269].}

(but) parenthesized words are possible hearings

(( )) transcriber's comments

but emphasis

- $\quad$ cut-off (bu-)

[ a point of overlap onset

(0.6) silences timed in 10ths of a second

(.) less than (0.2) of silence

$\mathrm{hh} / \mathrm{hh}$ hearable inhalation / exhalation

\section{References}

1. World Health Organization (WHO). Depression and other common mental disorders: global health estimates. Geneva: World Health organization. 2017. http://www.who.int/ mental_health/management/depression/prevalence global_health_estimates/en/. Accessed 13 Sept 2018.

2. Insel TR, Collins PY, Hyman SE. Darkness invisible: the hidden global costs of mental illness. Foreign Aff. 2015;94(1):127-35.

3. Banerjee S, Chatterji P, Lahiri K. Effects of psychiatric disorders on labor market outcomes: a latent variable approach using multiple clinical indicators. Health Econ. 2015;25(2):184-205.

4. Cornwell K, Forbes C, Inder B, Meadows G. Mental illness and its effects on labour market outcomes. J Ment Health Policy. 2009;12(3):107-18.

5. Hipes C, Lucas J, Phelan JC, White RC. The stigma of mental illness in the labor market. Soc Sci Res. 2016;56:16-25.

6. Stuart H. Mental illness and employment discrimination. Curr Opin Psychiatry. 2006;19(5):522-6.

7. Ala-Kauhaluoma M, Härkäpää K. Private service sector and employment of persons with weak labour market position. Helsinki: Ministry of Labour; 2006.

8. The Finnish Central Association for Mental Health. Mental health barometer. Helsinki: The Finnish Central Association for Mental Health and the Ministry of Social Affairs and Health; 2017.

9. Hickey G, Kipping C. Exploring the concept of user involvement in mental health through a participation continuum. J Clin Nurs. 1998;7(1):83-8.

10. Truman C, Raine P. Experience and meaning of user involvement: some explorations from a community mental health project. Health Soc Care Comm. 2002;10(3):136-43.

11. Sibitz I, Amering M, Unger A, et al. The impact of the social network, stigma and empowerment on the quality of life in patients with schizophrenia. Eur Psychiat. 2011;26(1):28-33.

12. Lysaker PH, Tsai J, Yanos P, Roe D. Associations of multiple domains of self-esteem with four dimensions of stigma in schizophrenia. Schizophr Res. 2008;98(1-3):194-200. 
13. Sibitz I, Unger A, Woppmann A, Zidek T, Amering M. Stigma resistance in patients with schizophrenia. Schizophr Bull. 2011;37(2):316-23.

14. Livingston JD, Boyd JE. Correlates and consequences of internalized stigma for people living with mental illness: a systematic review and meta-analysis. Soc Sci Med. 2010;71(12):2150-61.

15. Vauth R, Kleim B, Wirtz M, Corrigan PW. Self-efficacy and empowerment as outcomes of self-stigmatizing and coping in schizophrenia. Psychiatry Res. 2007;150(1):71-80.

16. Lundberg B, Hansson L, Wentz E, Björkman T. Stigma, discrimination, empowerment and social networks: a preliminary investigation of their influence on subjective quality of life in a Swedish sample. Int J Soc Psychiatry. 2008;54(1):47-55.

17. Rogers ES, Chamberlin J, Ellison ML, Crean T. A consumer-constructed scale to measure empowerment among users of mental health services. Psychiatry Serv. 1997;48(8):1042-7.

18. Corrigan PW, Faber D, Rashid F, Leary M. The construct validity of empowerment among consumers of mental health services. Schizophr Res. 1999;38(1):77-84.

19. Anthony WA. Toward a vision of recovery: for mental health and psychiatric rehabilitation services. Boston: Boston University Press; 2007.

20. Bensing J. Bridging the gap: the separate worlds of evidence-based medicine and patient-centered medicine. Patient Educ Couns. 2000;39(1):17-25.

21. Goss C, Moretti F, Mazzi MA, Del Piccolo L, Rimondini M, Zimmermann C. Involving patients in decisions during psychiatric consultations. $\mathrm{Br} \quad \mathrm{J}$ Psychiatry. 2008;193(5):416-21.

22. Department of Health. Framework for recovery-oriented practice. Melbourne: health, drugs and regions division, Victorian Government Department of Health; 2011. www. health.vic.gov.au/mentalhealth. Accessed 17 Sept 2018.

23. Lawson MA. The healing nature of communion: scottish psychoanalysis, R.D. Laing, and therapeutic communities. J Theor Philos Psychol. 2016;36(1):20-8.

24. Seikkula J. Becoming dialogical: psychotherapy or a way of life? Aust N Z J Fam Ther. 2011;32(3):179-93.

25. Garcia D, Lindskär E, Archer T. Thinking outside the box about indicators of well-being: agency, communion and positivity. Int J Happiness Dev. 2015;2(2):182-91.

26. Anderson S. We are not alone: Fountain House \& the development of Clubhouse culture. New York: Fountain House Inc; 1999.

27. Hänninen E. Choices for recovery: Community-based rehabilitation and the Clubhouse Model as means to mental health reforms. Tampere: University Print Oy; 2012. THLreport 50/2012.

28. McKay C, Nugent KL, Johnsen M, Eaton WW, Lidz CW. A systematic review of evidence for the Clubhouse model of psychosocial rehabilitation. Adm Policy Ment Hlth. 2018;45(1):28-47.

29. Clubhouse International. Quality Standards. 2018. http:// clubhouse-intl.org/resources/quality-standards/. Accessed 17 Sept 2018.

30. Pernice-Duca F, Onaga E. Examining the contributions of social network support to the recovery process among
Clubhouse members. Am J Psychiatry Rehab. 2009;12(1):1-30.

31. Raeburn T, Halcomb E, Walter G, Cleary M. An overview of the Clubhouse model of psychiatric rehabilitation. Australas Psychiatry. 2013;21(4):376-8.

32. Raeburn T, Schmied V, Hungerford C, Cleary M. Clubhouse model of psychiatric rehabilitation: how is recovery reflected in documentation? Int J Ment Health Nurs. 2014;23(5):389-97.

33. Raeburn T, Schmied V, Hungerford C, Cleary M. The use of social environment in a psychosocial clubhouse to facilitate recovery-oriented practice. BJPsych Open. 2016;2(2):173-8.

34. Raeburn T, Schmied V, Hungerford C, Cleary M. Autonomy support and recovery practice at a psychosocial clubhouse. Perspect Psychiatry C. 2017;53(3):175-82.

35. Tanaka K, Davidson L. Meanings associated with the core component of Clubhouse life: the work-ordered day. Psychiatry Q. 2015;86(2):269-83.

36. Tanaka K, Craig T, Davidson L. Clubhouse community support for life: staff-member relationships and recovery. J Psychosoc Rehabil Ment Health. 2016;2(2):131-41.

37. Tanaka K, Davidson L. Reciprocity in the Clubhouse context. Int J Psychosoc Rehabil. 2015;19(2):21-33.

38. Doyle A, Lanoil J, Dudek K. Fountain house: creating community in mental health practise. New York: Columbia University Press; 2013.

39. Mandiberg JM, Edwards M. Collective identity formation in the mental health Clubhouse community. Int J Self-Help and Self-Care. 2013;7(1):19-39.

40. Mowbray C, Lewandowski L, Holter M, Bybee D. The clubhouse as an empowering setting. Health Soc Work. 2006;31(3):167-79.

41. Meeuwisse A. Vänskap och organisering —en studie av Fountain House-rörelsen. [Friendship and organization-a study of the Fountain House movement]. Lund: Studentlitteratur; 1997.

42. Karlsson M. Fountain House. In: Borkman T, Karlsson M, Munn-Giddings C, Smith L, editors. Self-Help and mental health: case studies of mental health self-help Organizations in US, England and Sweden. Stockholm: Sköndalsinstitutes Research Department; 2005. p. 95-106.

43. Crowther R, Marshall M, Bond GR, Huxley P. Vocational rehabilitation for people with severe mental illness. Cochrane Database Syst Rev. 2001;2:CD003080.

44. Hietala O, Valjakka S, Martikka N. Here you work for yourself." Clubhouses and member houses as new alternatives in rehabilitation and employment. Helsinki: Rehabilitation Foundation; 2000.

45. Pirttimaa R, Saloviita T. Transitional employment and its effects in Finland. Psychiatry Rehabil J. 2009;32(3):231-4.

46. Henry AD, Barreira P, Banks S, Brown J-M, McKay C. A retrospective study of clubhouse-based transitional employment. Psychiatry Rehabil J. 2001;24(4):344-54.

47. Peräkylä A, Vehviläinen S. Conversation analysis and the professional stocks of interactional knowledge. Discourse Soc. 2003;14(6):727-50.

48. Schegloff EA. Sequence Organization in Interaction: A Primer in Conversation Analysis. Cambridge: Cambridge University Press; 2007. 
49. Maynard DW, Peräkylä A. Language and social interaction. In: Delamater J, editor. Handbook of social psychology. New York: Plenum; 2003. p. 233-57.

50. Linell P, Hofvendahl J, Lindholm C. Multi-unit questions in institutional interactions: sequential organizations and communicative functions. Text. 2003;23(4):539-71.

51. Stivers T, Rossano F. Mobilizing response. Res Lang Soc Interact. 2010;43(1):3-31.

52. Stevanovic M, Valkeapää T, Weiste E, Lindholm, C. Osallisuus ja yhteinen päätöksenteko mielenterveyskuntoutuksessa [Participation and the promotion of joint decision making in mental health rehabilitation]. Psykologia-lehti (Forthcoming).

53. Bond GR, Dincin J. Accelerating entry into transitional employment in a psychosocial rehabilitation agency. Rehabil Psychol. 1986;31(3):143-55.

54. Bond GR, Drake RE, Becker DR, Mueser KT. Effectiveness of psychiatric rehabilitation approaches for employment of people with severe mental illness. J Disabil Policy Stud. 1999;10(1):18-52.

55. Gumber S, Stein CH. Beyond these walls: can psychosocial clubhouses promote the social integration of adults with serious mental illness in the community? Psychiatry Rehabil J. 2018;41(1):29-38.

56. Whitley RE, Drake RE. Dimensions of recovery. Psychiatry Serv. 2010;61:1248-50.

57. Chen F. Building a working community: staff practices in a Clubhouse for people with severe mental illness. Adm Policy Ment Hlth. 2017;44(5):651-63.

Publisher's Note Springer Nature remains neutral with regard to jurisdictional claims in published maps and institutional affiliations. 